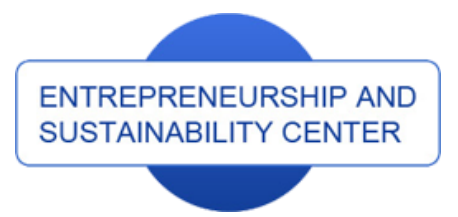

Publisher

http://jssidoi.org/esc/home

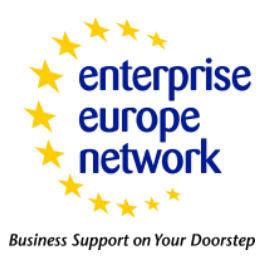

CASPA

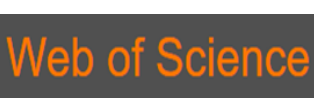

1) Clarivate

Analytics

\title{
DEVELOPMENTAL REVIEW PROGRAM IMPACT ON ENHANCING THE EFFECTIVENESS OF "TEACHING AND LEARNING" IN ACCOUNTING PROGRAM: A CASE STUDY IN A SAUDI UNIVERSITY*
}

\author{
Nabil Ahmed Mareai Senan \\ Department of Accounting, College of Business Administration, Prince Sattam Bin Abdulaziz University, Al-Kharj, Saudi \\ Arabia \\ E-mail: ${ }^{1}$ n.senan@psau.edu.sa
}

Received 20 September 2018; accepted 15 December 2018; published 30 December 2018

\begin{abstract}
Liberalization and globalization has opened up new and compelling challenges in the higher education section. Quality is invariably one of the factors that help educational institutions to remain relevant and thrive in the current highly competitive scenario, Quality in higher education is, as such, a hot topic and there is no paucity of literature in this regards. However, a fair review of the literature showed that there is scant literature about the impact of developmental review for enhancing of effectiveness of accounting program. The present work has attempted to bridge this gap in literature. The study has focused on Standard four - "Education and Learning" in the accounting program of a university in Saudi Arabia. The results of the study showed that there is profound positive impact of the developmental review towards the implementation of the requirements of standard four in the program. A few suggestions based on the study are also presented.
\end{abstract}

Keywords: Higher education; Accreditation; Developmental review Program; NCAAA; Standard four; Teaching and Learning

Reference to this paper should be made as follows: Senan, N.A.M. 2018. Developmental review program impact on enhancing the effectiveness of "Teaching and Learning" in accounting program: a case study in a Saudi University, Entrepreneurship and Sustainability Issues 6(2): 1001-1017. http://doi.org/10.9770/jesi.2018.6.2(35)

JEL Classifications: M40, 123

\footnotetext{
* This project was supported by the Deanship of Scientific Research at Prince Sattam Bin Abdulaziz University, Al-Kharj, Saudi Arabia under the research project \#2015/02/4273.
}

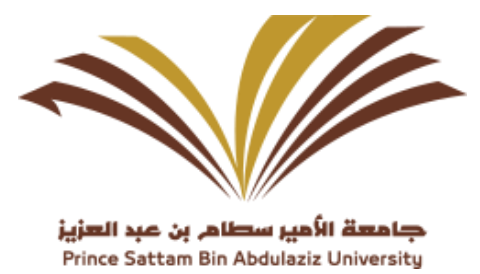




\section{Introduction}

The higher education scenario in general and business education in particular has undergone significant transformations in recent past. Globalization and disruptive technological changes in the external environment have forced educational institutions to involve in innovation and all round quality improvement. Accreditation is now increasingly being identified as one of the best ways to be noticed in the crowd (Zammuto, 2008). As early as in 1964, MacKenzie stated that accrediting educational institutions serve two purposes:

- Assisting of the general public to identify quality institutions and/or programs that meet the required minimum standards

- Enhancing the overall quality of education by providing a minimum standard for excellence.

In general, accreditation process is considered tohelp in improving the all-round quality of education and embarks on a continuous improvement program.

Saudi Arabia is now in a transition phase -from resource based economy to that of a knowledge based economy. To cater to this radical change, Saudi Arabian graduates are required to acquire the appropriate knowledge, skills and attitudes; such that they are prepared to deal with any unforeseen problems. Towards this, they should develop qualities to arrive at quick and creative solutions to complex problems. With this mindset, various education providers are putting in their best and sustained efforts to make them stand apart from the crowd. Almost all the universities and higher education institutions in Saudi Arabia are now striving to improve their allroundquality and embark on a continuous improvement program through accreditation process.

The Saudi Government is focusing on quality of higher education in two dimensions. It is simultaneously aiming at enhancing the efficiency and effectiveness of each institution, and at the same time creation of a national education system that is strong and coherent (Onsman, 2011). To achieve this, the Government is creating a wide network of complementary Higher Education institutions. The Ministry of Education has also embarked on a systematic plan of accreditingall academic institutions within a given time frame. It is with objective in mind that the National Commission for Assessment and Academic Accreditation (NCAAA) was established in the year 2004. NCAAA is the responsible authority for academic accreditation and quality assurance of higher educational institutions in the kingdom.NCAAA is authorized to tie the funding of higher education institutions to compliance of the quality standards. Overall, the acceptance of national guidelines of "quality, finance, scientific research, scholarships, and strategic planning" by individual institutions is considered as having paramount importance (Onsman, 2011).

Guided by the NCAA Quality Code, which presents the required benchmark statements; the Quality Assurance Agency (QAA) provides guidance about the requirementsof higher education expectations. The QAA conducts reviews of the institutions and brings out reports that highlight good practices, and makes recommendations for improvement of the academic standards and quality. It also comments on the level at which an institution attains its institutional responsibilities. Another body that is involved in enhancing the quality in the higher education sector is the National Qualification Framework (NQF). The NQF stipulates five distinct learning domains. There should be not more than eight Course learning outcomes, which in turn is to be in alignment with one or more of thelearning domains. It also stipulates a"program learning outcome matrix map", which identifies the program learning outcomes that are to be incorporated into individual courses.

A few commentators have looked at the position of accreditation of Saudi educational institutions. In thisregard, the comment of Onsman (2011) is worth considering: 
Despite the best intentions of the NCAAA, quality assurance mechanisms are far from universally in place, let alone adhered to-especially in the newer universities. Both pedagogically and philosophically, the use of English as the medium of instruction requires a great deal more consideration and careful development (p. 530).

With this comment at the backdrop, it is attempted to have a cursory look at the accreditation process in the accounting department of a University of Saudi Arabia. Based on this the objectives of the study are set.

\section{Objectives of Research:}

The main objective of the study is to know the impact of developmental review program for Academic Accreditation by NCAAA on enhancing the effectiveness of Standard four - "Education and Learning" in accounting program.

Standard four states that there should be clear specification about student learning outcomes which is consistent with NQF stipulations. This has to be assessed against the required "external reference points". It also states that the teaching staff must have appropriate qualification and experience. The teaching staffs are required to use appropriate teaching strategies that would bring out the required learning outcomes. They are expected to involve in activities that are capable of improving their teaching effectiveness. Assessment of students, survey of graduates and employers are to be used for evaluation of quality of teaching and effectiveness of the programs. Improvement plans are to be devised based on these assessments and surveys.A brief description of Standard four is provided in the Annexure.

The following sub-objectives are also set for the study:

1) To know how developmental review program impacts Academic Accreditation (NCAAA) towards enhancing the effectiveness of students' learning outcomes, students' assessment, educational assistances to the students, quality of teaching, support the efforts to improve the quality of teaching and qualifications of faculty members and their experiences.

2) To know the challenges that stand in the way of executing the criteria of standard four effectively. This will contribute to identify the main obstacles and priorities of improvement required for Accounting Program.

3) To propose appropriate mechanisms to develop the quality of Accounting Program in the light of requirements of NCAAA.

\section{Literature Review}

Many studies have been undertaken around the globe to ascertain the effectiveness of accreditation process. A review of literature shoes that the studies in this regards have thrown our mixed and conflicting results. Some areas in which research has been conducted include retention rates (Espiritu, 2007), student outcome (Lejeune and Vas, 2009), research output (Ehie and Karathanos, 1994; Udell et al., 1995; Hedrick et al., 2010), program improvement (Elliottand Goh, 2013), organizational effectiveness (Elliottand Goh, 2013; Lejeune and Vas, 2009), etc.

Espiritu (2007) conducted a study on the retention and graduation rates of accredited institutions. The study found higher rates of retention and graduationin accredited institutions. Student outcome was the topic of research of Lejeune and Vas (2009). They found that the accreditation process succeeded in contributing toward effectiveness measures. However, it need not necessarily contribute towards student outcomes. Research output in accredited institutions was a topic of empirical analysis by many (Ehie and Karathanos, 1994; Hedrick et al., 2010; Udell et al., 1995). All the studies revealed higher research productivity and/or perceived importance of 
intellectual contributions. Increased focus on both quality and research was also observed by Elliottand Goh (2013).

Another area were substantial research was done was instructional effectiveness/program improvement. Elliottand Goh (2013) found that accreditation is capable of serving as a catalyst for change andcan brings in program improvement. However, Pritchard et al. (2010) measured instructional effectiveness at an AACSB accredited US colleges of business. They found no change in instructional effectiveness over a period of sixyears. In a recent study Novakovich (2017) found that accreditation helps substantially in the design, implementation, and evaluation of learning activities. This could ultimately result in all round higher quality and effective learning experiences.

Organizational effectiveness is another area were substantial research has emerged (Lejeune and Vas, 2009; Sulphey and Alkahtani, 2017). Lejeune and Vas (2009) measured organizational effectiveness as a result of accreditation and found that it contributed toward certain effectiveness measures likeresource acquisition. A comprehensive study by Elliottand Goh (2013) found that accreditation facilitated organizational learning, promoted strategic alignment, a re-assessment of institutional mission by all concerned, and an emphasis on performance management, leadership and resource dependence. For a better understanding the research results are presented in a table (Table 1).

Table 1. Factors that changed as a result of accreditation and the authors

\begin{tabular}{|c|l|l|}
\hline No & \multicolumn{1}{|c|}{ Factors } & \multicolumn{1}{c|}{ Authors } \\
\hline 1 & Retention rates & Espiritu (2007); Womack andKrueger(2015) \\
\hline 2 & Graduation rates & Espiritu, 2007 \\
\hline 3 & Student/learning outcome & Lejeune and Vas (2009), (Welsh and Dey, 2002; Shupe, 2007). \\
\hline 4 & Research & Elliottand Goh (2013); Ehie and Karathanos (1994); Udell, Parkerand \\
& & $\begin{array}{l}\text { Pettijohn (1995); Hedrick, Henson, Krieg and Wassell (2010):Elliottand Goh } \\
(2013) ; \text { Roberts, Johnson and Groesbeck (2006) }\end{array}$ \\
\hline 5 & Instructional & Elliottand Goh (2013); Novakovich (2017);Pritchard, Saccucci and Potter \\
& effectiveness/Program & $(2010)$ \\
\hline 6 & improvement & \\
\hline 7 & Quality & Elliottand Goh (2013); Lejeune and Vas (2009);Newman (2000); \\
\hline
\end{tabular}

It is also worthwhile to have a look at the studies that emerged in the Middle East and Saudi Arabia regarding accreditation of higher education institutions. It can be observed that, with the turn of the century, there has been renewed interest in the Middle East in general and Saudi Arabia in particular about the complex and multiple effects and influences of globalization on the Higher Education sector (Altbach 2010; Donn and Al Manthri 2010; Sulphey, 2017; Sulphey, AlKahtani and Syed, 2018). Saudi Arabia is now putting in renewed efforts to strategically raise the standards and quality of Higher Education at par with international benchmarks (Sulphey and Al-Kahtani, 2018). This is attempted to be attained by maintaining its distinctive cultural heritage (Onsman, 2011). A number of studies have emerged in this area too. A few of them include that of Romanowski (2017)

\section{Studies about Accreditation of Accounting Programs}

There exist only few program specific studies pertaining to accounting. A few studies in this area include that of Brown and Balke (1983), Campbell and Williamson (1983), Balke and Brown (1985), Kren et al. (1993),Bitter et al. (1999), Bitter (2014), etc. Most of these studies are in the form of surveys conducted on accounting educational administrators to identify their perceptions about the utility and value of accreditation of their 
The International Journal

ENTREPRENEURSHIP AND SUSTAINABILITY ISSUES

ISSN 2345-0282 (online) http://jssidoi.org/jesi/

2018 Volume 6 Number 2 (December)

http://doi.org/10.9770/jesi.2018.6.2(35)

programs. Bitter (2014) also determined whether this perceptions of accounting education administrators differed across various institutions that gained accreditation.

However, there are a few significant studies too. For instance, Sinning and Dykxhoorn (2001) identified the various benefits that accounting programs could obtain from the accreditation process. Some benefits, according to them include program improvement, enhanced attractiveness to various stakeholders, and enhanced reputation of the program. Kim et al (1996) analyzed the relation between the salaries of graduates of accredited accounting departments or colleges and those that were not accredited. The descriptive study concluded that the average starting salary of graduates of accounting program from accredited institutions are higher. This indicates that employers and recruiters recognize the quality of accredited accounting programs.

The study by Koh and Koh (1998) implemented a model to enhance quality atNanyang Technological University. Implementation of this model on the students of accounting program enabled the students to get the required knowledge and to acquire skills with high spirits.Hindi \& Miller (2010) studied the ability of existing accounting programs to get the graduates acquire skills and knowledge necessary to labor markets. They particularly focused on professional accounting skills, ability to solve the problems, communication skills, critical thinking skills, skills of dealing with IT and its use in addition to the skills of professional development of ethics and continuing education. They found that there is strong support towards providing professional accounting skills and knowledge, but very low support for professional development of ethics and continuing education. Another area that the study focused was on the importance of review and evaluation of quality of performance for accounting programs continuously, which have benefits for the program and its outcomes. They also found positive indication about the program to keep pace with the changes and developments happening in the labor market.

The study of Arlinghaus(2002) stressed on the importance of recommendation made by the accrediting institution in terms of some skills and practical experiences of teachers in the accounting departments in American universities. It was found that such recommendations are capable of contributing in increasing the effectiveness of accounting programs, as well as its environment. Certain other significant findings are that the time allocated by faculty members for scientific research, authoring and publication exceeded the overall time allocated to gain scientific skills. Based on the study he recommended that it would be ideal for a group of faculty members to focus on scientific research, authoring, publication and intellectual contributions; while another group focus on acquiring practical accounting experiences, interaction and engaging in the labor market. Mounce et al. (2004) studied the importance of experiences and scientific skills of faculty members of accounting departments in US universities attempting to get academic accreditation from AACSB.

The study of Watty (2005), conducted in Australian universities, assessed the viewpoints of faculty members of accounting programs. The study examined the importance of the role of faculty members in designing of the program, its contents and its implementation; and its contribution towards developing a professional career. It also evaluated the extent of considerations provided for the requirements of the profession, the institution, quality standards, government, beneficiaries of the program, experiences and abilities of faculty members and their role in designing the program and its course. The study produced many significant results. The most important being the fact that the views and opinions of various samples were different with respect to the concepts of quality for accounting education. The importance of achieving general objectives from accounting programs was also stressed. Studis have also identified the importance and the role of faculty members in bridging the gap between the skills and knowledge gained from education and requirements of the labour market (Sulphey and Alkahtani, 2017). Another study by Weisenfeld and Robinson - Backmon (2007) examined the views of faculty members of accounting programs of several American universities. The views of faculty members belong to various sociodemographics were ascertained. Aspects like characteristics of teaching cadre, quality of work environment under based on ethnicity or gender, extent of preparation to work, etc. were examined. The study found diversity in 
The International Journal

ENTREPRENEURSHIP AND SUSTAINABILITY ISSUES

ISSN 2345-0282 (online) http://jssidoi.org/jesi/

2018 Volume 6 Number 2 (December)

http://doi.org/10.9770/jesi.2018.6.2(35)

terms of ethnicity and gender in the teaching cadre. The study highlighted the importance of providing a sound academic environment for faculty members and the importance of clear and specific plans and strategies for the programs.

Gaharan et al. (2007) examined the benefits, problems and challenges of accounting accreditation from AACSB. It also discussed the challenges and difficulties faced by institutions that are not accredited. This comprehensive study identified a host of positive impacts of accounting departments that are accredited. They found that accreditation process resulted in better involvement by the respective advisory boards, having a scientific performance evaluation process in place for the faculty, curriculum improvement, overall quality improvement of students and faculty, and last but not the least - better placement for the graduates. A few other benefits include:

- "Developing of regulations for faculty members pertaining to promotion, annual evaluation and further recruitment,

- Developing of a curriculum that reflects positively on students so as to make them suitable for the current labor market,

- Developing and updating the mission of the program and activation of the role of advisory councils by including various stakeholders.”

The study also succeeded in bringing out the various challenges faced by the faculty members on the works assigned to them for academic accreditation. Other limitations identified include limited funding, difficulty in getting the required support for office works, no compensation for extra work, etc. The study also succeeded in presenting several recommendations that could assist the accounting programs in getting accreditation.

The various studies conducted in the accounting programs are presented in a chronological order in the following table (Table 2).

Table 2. Findings conducted in accounting programs

\begin{tabular}{|c|c|c|}
\hline Factor studied & Author(s) & Findings \\
\hline $\begin{array}{l}\text { Salaries differences of } \\
\text { graduates from accredited } \\
\text { institutions }\end{array}$ & Kim et al (1996) & $\begin{array}{l}\text { - The average starting salary of graduates of accounting program } \\
\text { from accredited institutions are higher than that of non-accredited } \\
\text { institutions }\end{array}$ \\
\hline $\begin{array}{l}\text { Ability of programs to help } \\
\text { graduates acquire skills } \\
\text { and knowledge based on } \\
\text { labor markets }\end{array}$ & $\begin{array}{l}\text { Hindi \& Miller } \\
(2010)\end{array}$ & $\begin{array}{l}\text { - Strong support was found towards providing professional } \\
\text { accounting skills and knowledge, but very low support was found } \\
\text { for professional development of ethics and continuing education. }\end{array}$ \\
\hline Benefits from accreditation & $\begin{array}{l}\text { Sinning \& } \\
\text { Dykxhoorn } \\
(2001) \\
\text { Gaharan et al. } \\
(2007)\end{array}$ & $\begin{array}{l}\text { - Program improvement, enhanced attractiveness to various stake } \\
\text { holders, and enhanced reputation of the program } \\
\text { - Better involvement by the respective advisory boards, scientific } \\
\text { performance evaluation process for the faculty, curriculum } \\
\text { improvement, overall quality improvement of students and faculty, } \\
\text { and better placement for the graduates. }\end{array}$ \\
\hline $\begin{array}{l}\text { Role of faculty in } \\
\text { designing a professional } \\
\text { program }\end{array}$ & Watty (2005) & $\begin{array}{l}\text { - Faculty members are capable of bridging the gap between the skills } \\
\text { and knowledge gained from accounting education and } \\
\text { requirements of the labour market. }\end{array}$ \\
\hline
\end{tabular}

A review of literature thus shows that most of these studies were conducted either in the USA, Europe or Australia. A fair review by the researcher failed to find out any worthwhile study conducted in Saudi Arabia or even in the Middle East. The present study attempts to bridge this gap in literature. 


\section{Research methodology}

The present research relied upon Inductive, Deductive as well as Descriptive and Analytical Approach.

Inductive approach extrapolates the previous studies and writings related to the topic of research and extract logical conclusions which can help to meet the research objectives. Deductive approach is intended to attempt to design a model through which the quality of educational system of accounting program can be evaluated from the perspective of NCAAA. Descriptive and Analytical Approachis used to diagnose and analyze the sub-standards of Standard four related to education and learning with the aim to design "improvement plan" for these standards. It is expected that this will contribute towards enhancement of the effectiveness of Standard four.

\section{Research Tool}

Questionnaire method was used to ascertain the views of those concerned with the quality of accounting program like faculty members of accounting, students, and graduates of the university under study.

\section{Research Methods}

The method used for the study included both desk study and test study methods. Desk Study Method was used to collect the necessary data to formulate the theoretical aspects of the study through knowing the references relevant to the topic of the research. The Test Study Method was used to test the extent of acceptance or rejection of research hypotheses.

\section{Research Community and Sample}

The research community comprised of faculty members in the department nominated for program academic accreditation, regular students and the graduates formed the community for research. The sample size for the study consisted of three hundred and three respondents, distributed between the three groups sated above. Data was collected with the help of a questionnaire distributed to the four following categories:

- First Category: This consisted of 222 students undergoing accounting program in the university.

- Second Category: This consisted of graduates from the department of accounting. 53 respondents responded to the study.

- Third Category: This included all faculty members (28) of Accounting Program in the University.

Table 3 presents the detailed description of the sample of the study.

Table 3. Frequency of the Three Sample Groups

\begin{tabular}{|l|l|l|l|l|}
\hline Groups & Frequency & Percent & Valid Percent & Cumulative Percent \\
\hline Student & 222 & 73.27 & 73.27 & 73.27 \\
\hline Graduate & 53 & 17.49 & 17.49 & 90.76 \\
\hline Teaching Staff & 28 & 9.24 & 9.24 & 100 \\
\hline Total & 303 & 100 & 100 & \\
\hline
\end{tabular}


The International Journal

ENTREPRENEURSHIP AND SUSTAINABILITY ISSUES

ISSN 2345-0282 (online) http://jssidoi.org/jesi/

2018 Volume 6 Number 2 (December)

http://doi.org/10.9770/jesi.2018.6.2(35)

\section{Analysis of Data}

The second part of the questionnaire contained details about the impact of developmental review program for academic accreditation (NCAAA) on enhancing the effectiveness of standard four "Education and Learning" and its determinants in accounting program. This data was analyzed using SPSS 21.0 software and Gretl 1.8.0 (Gnu Regression, Econometrics and Time-series Library).

The questionnaire had several elements of criterions under Standard Four and their practices. This specifies the extent of quality and availability of these determinants that in turn point the overall rating of the developmental review program impact for academic accreditation (NCAAA), and enhances the effectiveness of these practices in the Accounting Program. For have a comprehensive view, the data was gathered from three groups of stockholders (students, graduates, and teaching staffs).

\section{Test of Normality}

The researcher has utilized two type of statistical normal distribution test, Shapiro-Wilk and Kolmogorov-Smrnov toexamine the distribution of the responses.It was found that all responses distributed normally with statistical significance.A significantly lower chi-square value in an unconstrained model indicates that discriminate validity wasachieved. Convergent validity is assessed from the measurement model by determining whether each indicator is estimated pattern coefficient on its posited underlying construct factor is significant. The value of Cornbach's Alpha for all elements of scale was 97.1 per cent this value indicates excellent reliability percentage.

Testing the impact of developmental review program for accreditation on teaching and learning standard

Bitter (2014), Bitter, et al (1999), and Gaharan, et al (2007) have highlighted the need for development review towards accreditation of accounting programs. Based on these studies, the objective of the study was set to test the impact of developmental review program for accreditation on teaching and learning standard. To test this, the researcher used one-way t-test and correlation for the three groups. The results are presented in the following sections:

\section{Impact of Developmental Review Program for the Students' Group}

Shupe (2007) has presented the various benefits of focusing on the student learning outcomes. This is one of the most important criterion as regards to accreditation of any program. The impact of the Developmental Review Program based on student perception is presented in Table 4. It can be observed the overall mean is 3.47, which greater than 3 (elementary mean). The value of $\boldsymbol{t}$ was 10.082, greater than $\boldsymbol{t}_{\boldsymbol{a}}=1.962$, with high level of statistical significance. In addition, the level of the impact of developmental review program for accreditation on teaching and learning standard of this group was $61.73 \%$, which shows that there is positive impact of the developmental review program on the accounting program. Further, positive impact can also be observed on the implementation of all the four sub standards and their practices in the accounting program. The value of $t$ for these sub-standards can be found to be11.411, 7.636, 7.160, and 10.212. These denote that all the elements of the criterion present a strong positive impact. 
Table 4. $t$ Test for the Impact of Developmental Review Program on in the Accounting Program for the Students Group

\begin{tabular}{|l|l|l|l|l|l|l|l|}
\hline Elements & $\mathrm{N}$ & $\mathrm{df}$ & Mean & $\begin{array}{l}\text { Std. } \\
\text { Deviation }\end{array}$ & $t$ & $\begin{array}{l}\text { Sig. } \\
\text { tailed) }\end{array}$ & $\%$ \\
\hline Students Learning Outcomes & 222 & 221 & 3.53 & 0.687 & 11.411 & 0.000 & 63.16 \\
\hline Students Evaluation & 222 & 221 & 3.39 & 0.769 & 7.636 & 0.000 & 59.85 \\
\hline Educational Support for Students & 222 & 221 & 3.40 & 0.841 & 7.160 & 0.000 & 60.10 \\
\hline Teaching Quality & 222 & 221 & 3.55 & 0.807 & 10.212 & 0.000 & 63.82 \\
\hline Impact of Developmental Review Program & 222 & 221 & 3.47 & 0.694 & 10.082 & 0.000 & 61.73 \\
\hline
\end{tabular}

\section{Testing the Impact of Developmental Review Program for the Graduates' Group Review Program:}

The results of the test pertaining to the perception of the Graduates are presented in Table 5. From the table it can be seem that the mean value is 3.52 , which is greater than the elementary mean of 3 . The $t$ value was 4.792 , which is higher than $\boldsymbol{t}_{\boldsymbol{a}}(2.000)$, which is statistically significant. The level of developmental review program impact (DRPI) for accreditation on teaching and learning standard of this group was found to be63.12\%, indicating that it lies within the positive zone of developmental review program. This is in line with an earlier study by Brown and Balke (1983) that has examined the accounting curriculum comparison based on the programs for those intending to seek accreditation.

Based on the elements of standard four, a positive impact can be observed on the implementation of the four sub standards and their practices. The $t$ for the sub-standards was were 5.581, 3.794, 3.736, and 4.756, denoting positive impact of the Developmental Review Program.

Table 5. $t$ Test for the Impact of Developmental Review Program on in the Accounting Program for the Graduates Group

\begin{tabular}{|l|l|l|l|l|l|l|l|}
\hline Element & $\mathrm{N}$ & $\mathrm{df}$ & Mean & $\begin{array}{l}\text { Std. } \\
\text { Deviation }\end{array}$ & $\mathrm{t}$ & $\begin{array}{l}\text { Sig. (2- } \\
\text { tailed) }\end{array}$ & $\%$ \\
\hline Students Learning Outcomes & 53 & 52 & 3.58 & 0.756 & 5.581 & 0 & 64.49 \\
\hline Students Evaluation & 53 & 52 & 3.42 & 0.809 & 3.794 & 0 & 60.53 \\
\hline Educational Support for Students & 53 & 52 & 3.5 & 0.977 & 3.736 & 0 & 62.53 \\
\hline Teaching Quality & 53 & 52 & 3.6 & 0.915 & 4.756 & 0 & 64.94 \\
\hline Impact of Developmental Review Program & 53 & 52 & 3.52 & 0.798 & 4.792 & 0 & 63.12 \\
\hline
\end{tabular}

\section{Testing the Impact of Developmental Review Program for the Teaching Staff Group}

The need for complete faculty involvement in accounting accreditation was highlighted by Sinning and Dykxhoorn (2001). Campbell and Williamson (1983) in their study about accreditation of accounting programs have also considered the administrators' perceptions of quality standards, accorded prime importance to this aspect. In line with this the present study has also taken the perception of the faculty regarding developmental review of the program. Table 5 presents the perception of the teaching community about the developmental review program. It can observe from the table that in line with the earlier cases, the actual mean (3.60) is higher the elementary mean. Similarly the $t$ value (6.097) is also greater than $t_{a}$ (2.052), and is statistically significant. This positive impact also was observed for all the elements. The value of $t$ for the different criterion was found to be $9.738,5.442,5.474,5.086$ and 2.779 . 
The International Journal

ENTREPRENEURSHIP AND SUSTAINABILITY ISSUES

ISSN 2345-0282 (online) http://jssidoi.org/jesi/ 2018 Volume 6 Number 2 (December)

http://doi.org/10.9770/jesi.2018.6.2(35)

Table 5. $t$ Test for the Impact of Developmental Review Program on in the Accounting Program for the Teaching Staff Group

\begin{tabular}{|l|l|l|l|l|l|l|l|}
\hline Element & N & df & Mean & $\begin{array}{l}\text { Std. } \\
\text { Deviation }\end{array}$ & t & $\begin{array}{l}\text { Sig. }(2- \\
\text { tailed) }\end{array}$ & $\%$ \\
\hline Students Learning Outcomes & 28 & 27 & 3.87 & 0.471 & 9.738 & 0.000 & 71.68 \\
\hline Students Evaluation & 28 & 27 & 3.54 & 0.521 & 5.442 & 0.000 & 63.39 \\
\hline Educational Support for Students & 28 & 27 & 3.61 & 0.587 & 5.474 & 0.000 & 65.18 \\
\hline Teaching Quality & 28 & 27 & 3.56 & 0.581 & 5.086 & 0.000 & 63.95 \\
\hline Improvement of teaching quality & 28 & 27 & 3.44 & 0.830 & 2.779 & 0.010 & 60.89 \\
\hline Impact of Developmental Review Program & 28 & 27 & 3.60 & 0.521 & 6.097 & 0.000 & 65.02 \\
\hline
\end{tabular}

Correlation between the deferent Determinants

The correlation between the deferent determinants and developmental review program impact is presented in Table 6. All the correlations were positively statistically significant at 0.01 level.Thus, it can be found that there is significant relationship between determinants for the three groups. The direction of the correlation is evident in Figure 1. This denotes that any increase in any element of the development review program could have its impact in enhancing the standard four.

Table 6.Spearman's Correlations of the Determinants for the three groups

\begin{tabular}{|c|c|c|c|c|c|}
\hline Element & $\begin{array}{l}\text { Students } \\
\text { Learning } \\
\text { Outcomes }\end{array}$ & $\begin{array}{l}\text { Students } \\
\text { Evaluation }\end{array}$ & $\begin{array}{l}\text { Educational } \\
\text { Support for } \\
\text { Students }\end{array}$ & $\begin{array}{l}\text { Teaching } \\
\text { Quality }\end{array}$ & $\begin{array}{l}\text { Impact of } \\
\text { Developmental } \\
\text { Review Program }\end{array}$ \\
\hline Students Learning Outcomes & 1.000 & & & & \\
\hline Students Evaluation & 0.748 & 1.000 & & & \\
\hline Educational Support for Students & 0.688 & 0.761 & 1.000 & & \\
\hline Teaching Quality & 0.678 & 0.716 & 0.830 & 1.000 & \\
\hline Impact of Developmental Review Program & 0.857 & 0.897 & 0.923 & 0.906 & 1.000 \\
\hline
\end{tabular}

Correlation is significant at the 0.01 level (2-tailed).

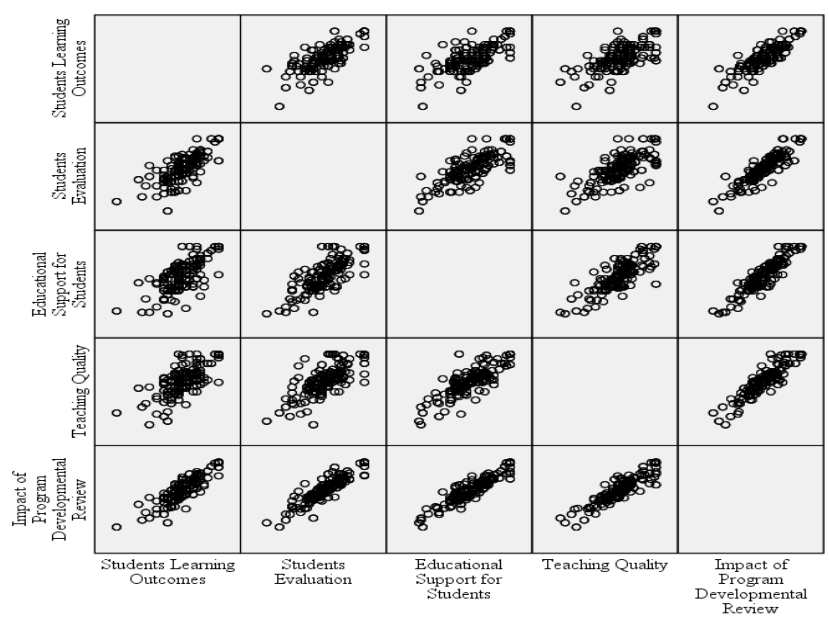

Figure 1. Spearman's Correlations of the Determinants for the three groups

\section{Testing the Developmental Review Program Impact with Different Groups}

In this phase, the researcher tested developmental review impact with different groups to know the variances in 
DRPI of different groups under study. One Way ANOVA that compares the means of the samples or groups was done to make inferences about the population means. Table 7 presents the results of ANOVA.

The Table consists of four parts. The first part contains the descriptive statistics, i.e., actual means and Std. deviation for the different groups. The second part (Test of Homogeneity of Variances) provides the Levene test. It can be see that the value of $p=0.087>(\alpha=0.05)$, denoting that the variances of dependent variable in the three groups are equal; i.e., not significantly different. Thus, the variances are homogeneous. The third part presents the results of the ANOVA test. The results denote that $\mathrm{F}$ there is no statistically significant difference in the mean among the three groups $(F=0.827, p=0.827>\alpha=0.05)$. The Post hoc test shows higher impact of developmental review program in enhancing the standard four in the accounting program. The means of the students, graduates, and teaching staff were $3.469,3.525$, and 3.642 respectively.

Table 7.Test of PDRI Level with the deferent groups of respondents

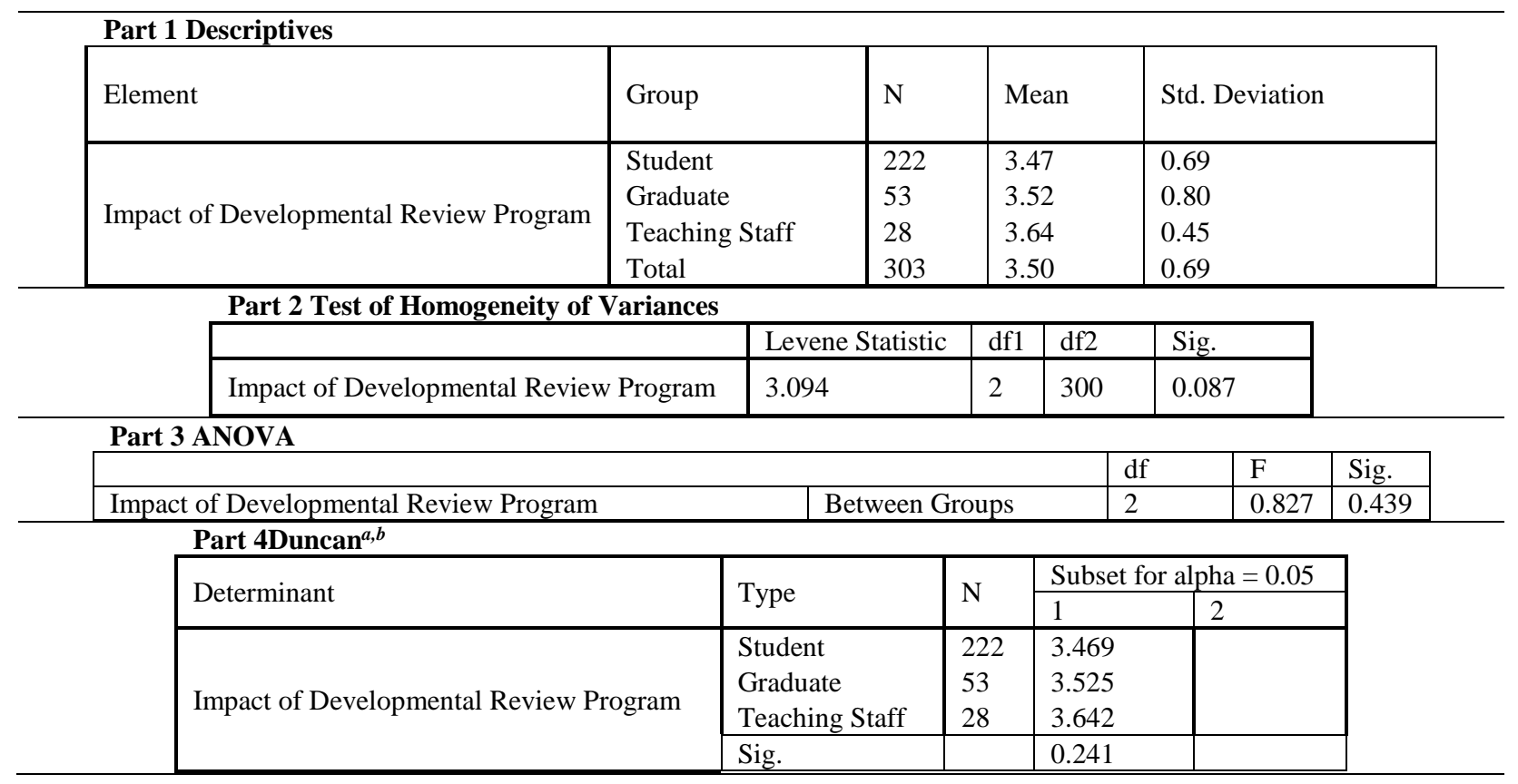




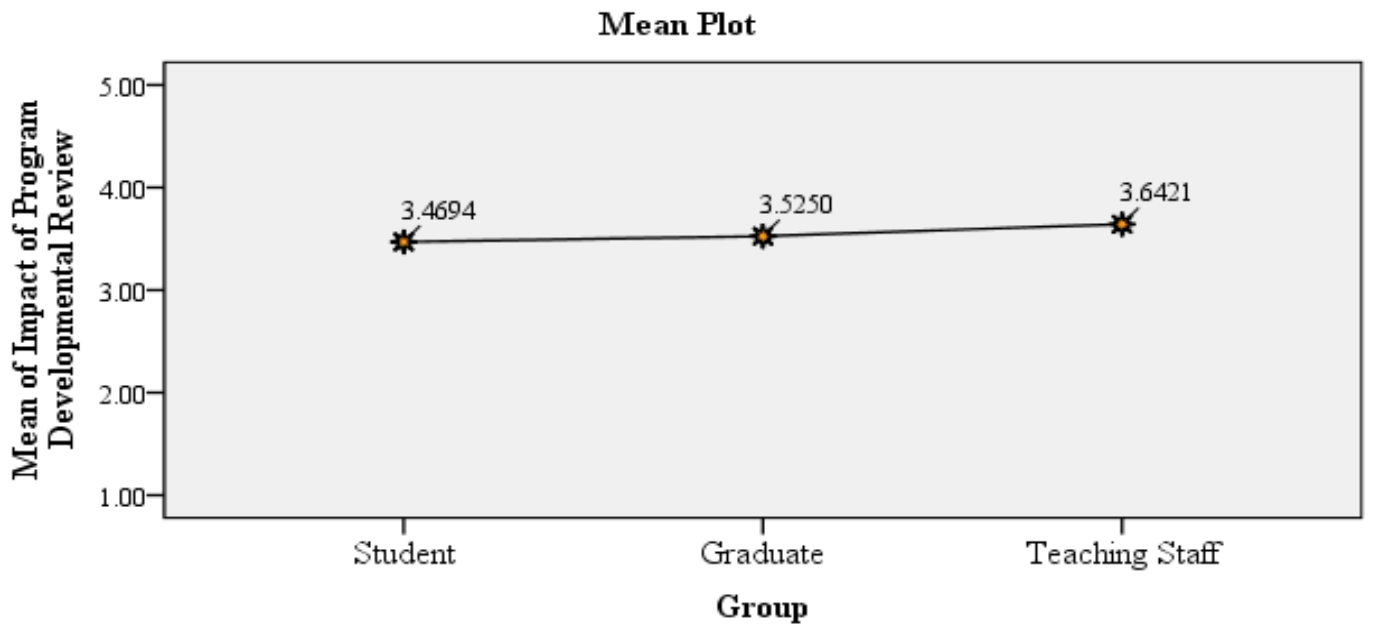

Figure 2.Testing the Impact of Developmental Review Program for the Three Group:

From Table 7 it can be seen that the actual mean is 3.50, which isgreater than the elementary mean of 3 . The $\boldsymbol{t}$ value (12.406) isgreater than $\boldsymbol{t}_{\boldsymbol{a}}=1.962$, which shows a high level of statistical significance. In addition, the level of DRPI for accreditation on teaching and learning standard was $62.38 \%$, denoting that there is positive impact of developmental review program towards the implementation of standard four requirements in the program. The Developmental Review Program showed positive impact on the implementation for the four sub standards with the value of $t$ for these sub-standards being 14.347, 9.488, 9.043, and 12.110 (Table 8). Hence, it can be inferred thatall the elements strengthen the positive impact of the Developmental Review Program and their practices in accounting program at the university.

Table 8. $t$ Test for the Impact of Developmental Review Program in enhancing the standard four in the Accounting Program.

\begin{tabular}{|l|l|l|l|l|l|l|l|}
\hline Element & $\mathrm{N}$ & $\mathrm{df}$ & Mean & $\begin{array}{l}\text { Std. } \\
\text { Deviation }\end{array}$ & $\mathrm{t}$ & $\begin{array}{l}\text { Sig. (2- } \\
\text { tailed) }\end{array}$ & \% \\
\hline Students Learning Outcomes & 303 & 302 & 3.57 & 0.688 & 14.347 & 0.000 & 64.18 \\
\hline Students Evaluation & 303 & 302 & 3.41 & 0.756 & 9.488 & 0.000 & 60.30 \\
\hline Educational Support for Students & 303 & 302 & 3.44 & 0.847 & 9.043 & 0.000 & 61.00 \\
\hline Teaching Quality & 303 & 302 & 3.56 & 0.807 & 12.110 & 0.000 & 64.03 \\
\hline Impact of Developmental Review Program & 303 & 302 & 3.50 & 0.695 & 12.406 & 0.000 & 62.38 \\
\hline
\end{tabular}

\section{Conclusion}

Though many studies have been conducted about accreditation of higher educational institutions in general and accounting in particular, no study has been undertaken in the dimension proposed by the researcher. The study was thus conducted to know the impact of developmental review program for Academic Accreditation by NCAAA on enhancing the effectiveness of Standard four - "Education and Learning" in accounting program.

Thus based on the analysis, the researcher has found that there exists a positive impact of development review program towards the enhancement of the standards for criterions and their practices in the accounting program at Sattam Bin Abdulaziz University. However, some practices need to be adopted to improve their implementation. A few of them are stated below:

1. Improve surveysystem for employers about the effectiveness and efficiency of program students 
learning outcomes.

2. Developing and implementing a system of evaluating students' performance externally.

3. Currently the student achievement is not systematically linked to the learning outcomes. There is a need to link the students' achievements with the intended learning outcomes by developing a measurement system.

4. There are multitudes of academic systems that need to be made aware to each student. The Academic systems of the program need to be put across to the students through developing a systematic mechanism.

5. Providing encouraging atmosphere and developing procedures to overcome difficulties faced by teaching staff. Special care need to be put in to improve all facilities for the faculty to develop their intellectual capital. A mechanism need also be in place to followup the aspects related to the development of teaching staff, as well as appropriately rewarding distinguished faculty.

It is expected that more studies will be undertaken to unveil the lacunas and bring in an impeccable system that will bring in a seamless teaching learning process. This will of paramount importance for brining in the badly required positive changes in the educational sector so as to make a bright future.

\section{Annexure}

\section{Standard Fourth: Learning and Teaching}

This standard focuses on evaluation of consistency of students' learning outcomes with National Qualification Framework - NQF and extent of consistency and effectiveness of teaching and evaluation methods with the domains of learning outcomes.

Required Evidences: It can be relied on evaluation of students, graduates and employers to measure the quality of program and learning outcomes as well as statistics of completion of course \& program, ratio of students to teaching staff, statistics of qualifications of teaching cadre, strategies of teaching and evaluation for different domains of learning, results of benchmarking with other universities through the samples of students' works, question papers and students' answers.

\section{Examples of Indicators:}

- Students' survey about the quality of teaching and filed activities.

- Graduates' survey about the quality of program, skills and knowledge required and needed by labor market.

- Employers' survey about the quality of graduates.

- Ratio of students to teaching staff and employees in the program as whole.

- Graduates employment rates.

- Percentage of success and completion of students from first year to second year.

- Percentages of graduates taken admission for higher studies in approved universities.

- External and independent evaluation of the program based on the criteria of NQF.

- Effectiveness of teaching methods as per the evaluation of students, external observers and faculty members for each domain of knowledge.

- Level of effectiveness of academic guidance and consultations given to students by faculty members.

- Qualifications and percentage of faculty members who have $\mathrm{PhD}$, Master and Bachelor Degrees. 


\section{ENTREPRENEURSHIP AND SUSTAINABILITY ISSUES \\ The International Journal}

ISSN 2345-0282 (online) http://jssidoi.org/jesi/ 2018 Volume 6 Number 2 (December)

http://doi.org/10.9770/jesi.2018.6.2(35)

- Appropriateness of qualifications and experience of faculty members for the courses they supervise.

- Opinions of external observers about the quality of approved course books of the program.

- Opinions of students about the course books in terms of its usefulness and understandable.

- Number of annually published researches of faculty members in peer reviewed journals.

- Opinions of consulting and professional bodies regarding quality of courses and whether it can cover the required skills and knowledge.

- Level of participation of faculty members in the activities of professional development related to teaching methods.

- Level of students' satisfaction about the effectiveness of teaching in the program.

- Percentage of appointment of graduate students.

- Percentage of graduates who got higher studies.

- Percentage of students who completed the study year with a grade of "Good".

\section{References}

Altbach, P. G. (2010). The Realities of Mass Higher Education in a Globalized World, "Higher Education in a Global Society, Edward Elgar Publishing. https://www.researchgate.net/publication/44832165 Globalization and the University Realities in an Unequal World

Arlinghaus, B. P. (2002).The Environment for Professional Interaction and Relevant Practical Experience in AACSB-Accredited Accounting Programs. Journal of Education for Business, 78(1). 38-45. https://doi.org/10.1080/08832320209599696

Balke, T. E., \& Brown, J. F. (1985). How new AACSB accounting standards are viewed. Management Accounting. January, 10-11.

Bitter, M. E. (2014). The Benefits of AACSB Accounting Accreditation: Perceptions of Administrators of Accounting Accredited Programs. Academy of Educational Leadership $\quad$ Journal, $\quad$ 18(1), https://www.abacademies.org/articles/aeljvol18no12014.pdf\#page=93

Bitter, M. E., Stryker, J. P. \& Jens, Jr. W.J. (1999). A preliminary investigation of the choice to obtain AACSB accounting accreditation. The Accounting Educators' Journal. XI. http://www.aejournal.com/ojs/index.php/aej/article/viewFile/12/13

Brown, Jr., J. F., \& Balke, T.E. (1983). Accounting curriculum comparison by degree program of schools intending to seek AACSB accreditation. Issues in Accounting Education. 50-59.

Campbell, D. R., \& Williamson, R.W. (1983). Accreditation of accounting programs: Administrators' perceptions of proposed AACSB standards. Issues in Accounting Education. 60-70.

Donn. G and Al Manthri, Y. (2010). Globalization and the Higher Education in the Arab gulf States, Symposium Books, Didcot, UK.

Ehie, I.C. and Karathanos, D. (1994). Business faculty performance evaluation based on the new AACSB accreditation standards. Journal of Education for Business, 69(5), 257-263. https://doi.org/10.1080/08832323.1994.10117695

Elliott, C. J. and Goh, S. C. (2013). Does accreditation promote organizational learning? A multiple case study of Canadian university business schools. Journal of Management Development, 32(7), 737-755. DOI: 10.1108/JMD-03-2011-0028

Espiritu, A. (2007). Is there a dividend to an institution for having an accredited college of business?, Journal of American Academy of Business, 11(1), 269-274.

Gaharan, C., Chiasson, M. A., Foust, K. M. \& Mauldin, S. (2007). AACSB International accounting accreditation: Benefits and challenges. The Accounting Educators' Journal, XVII. 13-29. http://www.aejournal.com/ojs/index.php/aej/article/view/61/52 
Hedrick, D., Henson, S., Krieg, J. and Wassell, C. (2010). The effects of AACSB accreditation on faculty salaries and productivity. Journal of Education for Business, 85(5), 284-291. https://doi.org/10.1080/08832320903449543

Hindi, N., Miller, D. (2010). A Survey of AssessmentPractices in Accounting Departments of Colleges and Universities. Journal of Education for Business, 75(5), 286-290. https://doi.org/10.1080/08832320009599030

Istileulova, Y.and Peljhan, D. (2015). Institutional Change as a Result of International Accreditation: Business Schools of Lithuania after the Iron Curtain. Economic and Business Review, 17(3), 291-312. https://doi.org/10.15458/85451.8

Kren, L., Tatum, K. W., \& Phillips, L. C. (1993). Separate accreditation of accounting programs: An empirical investigation. Issues in Accounting Education, 8(2), 260-272.

Kim, K., Rhim, J. C., Henderson, W.C., Bizal, N. F. and Pitman, G. A. (1996). AACSB Accreditation: A Positive Signal in Accounting Job Markets. The Mid - Atlantic Journal of Business, June, 32(2), 123 - 134.

Koh, H. C. and Koh, M. Y. (1998). Empirical Evaluation of Accounting Programs: A Proposed Factor -Analytic Approach. Journal of Accounting Education, 16(4), 295-314. https://doi.org/10.1016/S0748-5751(98)00013-X

Lejeune, C. and Vas, A. (2009). Organizational culture and effectiveness in business schools: a test of the accreditation impact. Journal of Management Development, 28(8), 728-741. https://doi.org/10.1108/02621710910985504

MacKenzie, O. (1964). Accreditation of accounting curricula. The Accounting Review. April, 363-370.

Mounce, P. H., Mauldin, D. S., Braun, R. L. (2004). The Importance of Relevant Practical Experience among Accounting Faculty: An Empirical Analysis of Student's Perceptions, Issues in Accounting Education, 19(4), 339-411. https://doi.org/10.2308/iace.2004.19.4.399

Newman, K. L. (2000). Organizational Transformation during Institutional Upheaval. Academy of Management Review, 25(3), 602-619. https://doi.org/10.2307/259313

Novakovich, E. M. (2017). Impact of Accreditation Standards on the Quality of Continuing Nursing Education Activities as Perceived by the Learner. The Journal of Continuing Education in Nursing, 48(4), 157-164. https://doi.org/10.3928/00220124-20170321-05

Onsman, A. (2011). It is better to light a candle than to ban the darkness: government led academic development in Saudi Arabian universities. Higher Education, 62, 519-532. https://doi.org/10.1007/s10734-010-9402-y

Pritchard, R., Saccucci, M. and Potter, G. (2010). Evaluating a program designed to demonstrate continuous improvement in teaching at an AACSB-accredited college of business at a regional university: a case study. Journal of Education for Business, 85(5) 280-283. https://doi.org/10.1080/08832320903449568

Roberts, W. A. Jr, Johnson, R., and Groesbeck, J. (2006). The Perspective of Faculty Hired after AACSB Accreditation on Accreditation's. Academy of Educational Leadership Journal; 10(3), 59-71. https://www.abacademies.org/articles/aeljvol10no32006.pdf

Romanowski, M. H. (2017). Neoliberalism and Western accreditation in the Middle East: A critical discourse analysis of Educational Leadership Constituent Council standards, Journal of Educational Administration, 55(1), 70-84. https://doi.org/10.1108/JEA-03-2016-0031

Shupe, D. (2007). Significantly better: the benefits for an academic institution focused on student learning outcomes. On the Horizon, 15(2), 48-57. https://doi.org/10.1108/10748120710757299

Sinning, K. E., \& Dykxhoorn, H. J. (2001). Processes implemented for AACSB accounting accreditation and the degree of faculty involvement. Issues in Accounting Education. May, 181-204. https://doi.org/10.2308/iace.2001.16.2.181

Sulphey, M. M. \& Al Kahtani, N. S. (2017). Economic security and sustainability through social entrepreneurship: the current Saudi scenario. Journal of Security and Sustainability Issues 6(3), 479-490. http://dx.doi.org/10.9770/jssi.2017.6.3(12)

Sulphey, M. M. \& Alkahtani, N. S. (2017). Organizational ambidexterity as a prelude to corporate sustainability. Journal of Security and Sustainability Issues, 7(2), 335-347. https://doi.org/10.9770/jssi.2017.7.2(13) 
The International Journal

ENTREPRENEURSHIP AND SUSTAINABILITY ISSUES

ISSN 2345-0282 (online) http://jssidoi.org/jesi/

2018 Volume 6 Number 2 (December)

http://doi.org/10.9770/jesi.2018.6.2(35)

Sulphey, M. M. \& Al-Kahtani, N. S. (2018). Academic Excellence of Business Graduates through Nudging: Prospects in Saudi Arabia. International Journal of Innovation and Learning, 24(1), 98-114. http://doi:10.1504/IJIL.2018.10013022

Sulphey, M. M. (2017). Game based learning as an aid for extenuating Higher Education Sector issues - The case of Saudi Arabia. International Journal of Simulation, Systems, Science and Technology, 18 (1), 6.1-6.10. https://doi.org/10.5013/IJSSST.a.18.01.06

Sulphey, M. M., Al-Kahtani, N. S. \& Syed, A. M. (2018). Relationship between Admission Grades and Academic Achievement. Entrepreneurship and Sustainability Issues, 5(3), http://doi.org/10.9770/jesi.2018.5.3(17).

Udell, G.G., Parker, S. and Pettijohn, C. (1995). An examination of the research productivity of marketing faculty at newly minted AACSB schools. Journal of Marketing Theory and Practice, 3(2), 106-113. https://doi.org/10.1080/10696679.1995.11501689

Watty, K. (2005). Quality in Accounting Education: What Say the Academics? Quality Assurance in Education, 13(2): 120-132. http://dx.doi.org/10.1108/09684880510594373

Weisenfeld, L. W., and Robinson-Backmon, I. B. (2007). Accounting Faculty Perceptions Regarding Diversity Issues and Academic Environment. Issues in Accounting Education, 22(3), 429-445. https://doi.org/10.2308/iace.2007.22.3.429

Welsh, J. F. and Dey, S. (2002). Quality measurement and quality assurance in higher education. Quality Assurance in Education, 10(1), 17-25. https://doi.org/10.1108/09684880210416076

Womack, J. Q andKrueger, T. M. (2015). The Impact of Initial Accreditation from AACSB on the Enrollment of Three South Texas Universities. Journal of Business Behavioral Sciences, 27(1), Spring 2015.

Zammuto, R.F. (2008). Accreditation and the globalization of business. Academy of Management Learning \& Education, 7(2), 256-268. https://doi.org/10.5465/amle.2008.32712623

\section{Aknowledgements}

This project was supported by the Deanship of Scientific Research at Prince Sattam Bin Abdulaziz University, Al-Kharj, Saudi Arabia under the research project \#2015/02/4273.

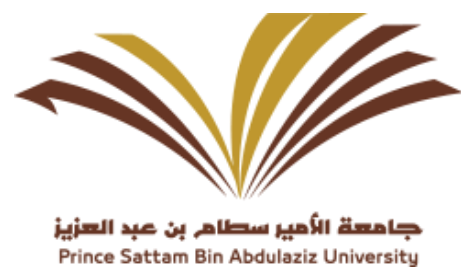


The International Journal

ENTREPRENEURSHIP AND SUSTAINABILITY ISSUES

ISSN 2345-0282 (online) http://jssidoi.org/jesi/

2018 Volume 6 Number 2 (December)

http://doi.org/10.9770/jesi.2018.6.2(35)

Dr. Nabil Ahmed Mareai SENAN is Director of Entrepreneurship center, College of Business Administration, Prince Sattam Bin Abdul Aziz University, Al-Kharj, Saudi Arabia, and ex Head, Accounting Department, College of Business Administration, Prince Sattam Bin Abdul Aziz University, Al-Kharj, Saudi Arabia. In addition, Dr. Nabil is Asst. Professor in Department of Accounting, College of Administration Science, Albaydha University, Yemen, as well as a Certified Public Accountant. Dr. Nabil has also involved in many activities and committees of Prince Sattam Bin Abdul Aziz University and has published a number of research articles in many international journals. His research interests include various areas in Accounting and Auditing.

ORCID ID: orcid.org/0000-0002-6848-588X

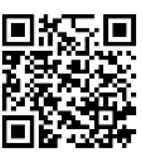

https://publons.com/a/1642303/

Copyright (C) 2018 by author(s) and VsI Entrepreneurship and Sustainability Center

This work is licensed under the Creative Commons Attribution International License (CC BY).

http://creativecommons.org/licenses/by/4.0/

cc) (7) Open Access 